\title{
MiR-22-3p Suppresses Cell Migration and Invasion by Targeting PLAGL2 in Breast Cancer
}

\author{
Tao Fan ${ }^{1}$, Chao-Qi Wang ${ }^{2}$, Xue-Tao Li ${ }^{1}$, Hong Yang ${ }^{1}$, Jun Zhou ${ }^{1}$ and Ying-Jie Song ${ }^{3}$ \\ ${ }^{1}$ The People's Hospital of China Three Gorges University, The First People's Hospital of Yichang. \\ ${ }^{2}$ Department of Urinary Surgery, Affiliated Hospital of Inner Mongolia University for the Nationalities, Tongliao Inner Mongolia, China \\ ${ }^{3}$ Department of General Surgery, The First People's Hospital of Yichang, Hubei Province, China
}

\begin{abstract}
Objective: To investigate the expression of $m i R-22-3 p$ in breast cancer and the mechanism of targeting PLAGL2 to inhibit the invasion and migration in human breast cancer.

Study Design: An experimental study.

Place and Duration of Study: Department of Oncology and Department of General Surgery, The People's Hospital of China Three Gorges University, China, from March 2019 to December 2020.

Methodology: The miR-22-3p expression level in 41 paired human primary breast invasive ductal carcinoma tissues and para-cancer tissues was obtained by real-time fluorescence quantitative reverse transcriptase PCR (qRT-PCR). The effect of miR-22-3p on the proliferation of breast cancer cells was detected by growth curve method. Online software TargetScan was used to predict the target genes of miR-22-3p. The prediction results were verified by luciferase reporter gene assay and qRT-PCR.

Results: MiR-22-3p expression was significantly decreased in the breast cancer tissues than in para-carcinoma normal breast tissues $(p<0.05)$. Over-expression of miR-22-3p can inhibit the proliferation of MCF-7 cells significantly. Pleomorphic adenoma gene-like protein 2(PLAGL2) is the predicted target gene of miR-22-3p. MiR-22-3p binds to its predicted target gene PLAGL2-3'UTR. The expression of miR-22-3p was negatively correlated with PLAGL2 in MCF-7 cells.

Conclusion: MiR-22-3p could suppress the proliferation of breast cancer by targeting PLAGL2. This suggests that miR-22-3p may be a strategy of choice for targeted therapy of breast cancer.
\end{abstract}

Key Words: Breast cancer, MiR-22-3p, PLAGL2, Cell proliferation.

How to cite this article: Fan T, Wang CQ, Li XT, Yang H, Zhou J, Song YJ. MiR-22-3p Suppresses Cell Migration and Invasion by Targeting PLAGL2 in Breast Cancer. J Coll Physicians Surg Pak 2021; 31(08):937-940.

\section{INTRODUCTION}

The latest global cancer burden data released in 2020 by the International Agency for Research on Cancer (IARC) of the World Health Organization (WHO) showed that the number of new cases of breast cancer increased rapidly, replacing lung cancer as the world's highest incidence cancer. Studies showed that approximately $50 \%$ of breast cancer patients, who receive systemic treatment, develop distant meta-stases. ${ }^{1,2}$

MiRNAs play a key role in the occurrence and development of breast cancer by binding to the $3^{\prime}$-untranslated region (3'-UTR) of target genesand silencing geneexpression after transcription; and participate in the regulation of tumor proliferation and metastasis. ${ }^{3,4}$

Correspondence to: Dr. Ying-Jie Song, Department of General Surgery, The People's Hospital of China Three Gorges University, The First People's Hospital of Yichang,

Hubei Province, China

E-mail:123525090@qq.com

Received: March 15, 2021; Revised: June 14, 2021;

Accepted: July 14, 2021

DOI: https://doi.org/10.29271/jcpsp.2021.08.937
The aim of this study was to investigate the expression level of miR-22-3p in breast cancer and the regulatory mechanism of targeting PLAGL2 to inhibit the invasion and migration in human breast cancer, so as to provide a theoretical basis for the development of therapeutic agents with molecular targets of miR-22-3p.

\section{METHODOLOGY}

This study was conducted at the Department of Oncology and Department of General Surgery, The People's Hospital of China Three Gorges University, China from March 2019 to December 2020. Human breast cancer cell line MCF-7 was obtained from the Typical Cultures Preservation Committee Cell Bank, Chinese Academy of Sciences. Cell medium: DMEM, 10\% FBS, $100 \mathrm{IU} / \mathrm{mL}$ penicillin and $100 \mu \mathrm{g} / \mathrm{mL}$ streptomycin sulfate were cultured at $37^{\circ} \mathrm{C}$ with $5 \% \mathrm{CO}_{2}$. To determine the expression level of miR-22-3p in breast cancertissues, breast cancer tissues and para-cancerous tissues were collected from 41 patients, who underwent surgical treatment in the First People's Hospital of Yichang from March 2019 to December 2020. None of these patients received preoperative chemotherapy. 
First of all, RNA was extracted by Trizol method, and its concentration and purity were determined by Nanodrop 2000. Reverse transcription of mRNA and miRNA was performed, respectively. The conditions of CDNA synthesis were $50^{\circ} \mathrm{C}$ for 30 minutes and $85^{\circ} \mathrm{C}$ for 5 minutes. The next step was cell transfection. The authors inoculated MCF-7 cells into 6-well plates and transfected with miR-22-3p mimics or control sequence, miR-22-3p inhibitor and control sequence, respectively. In the transfection experiments, synthetic miR-22-3p mimics, a miR-22-3p inhibitor, the overexpression plasmid of the PLAGL2 gene and the respective negative controls were used according to the instructions of the Ribo FECT ${ }^{\mathrm{TM}} \mathrm{CP}$ Transfection Kit. RNA was extracted 48 hours after transfection. Secondly, MCF-7 cells were seeded into 6-well plates (2000/well). After cell adhesion, the cells were transfected with miR-22-3p mimics or control sequence, and CCK8 solution of $10 \mu \mathrm{L}$ was added to each well at 24, 48 and 72 hours of transfection. The absorbance at $450 \mathrm{~nm}$ was measured by microplate analyser for 1 hour. Thirdly, PLAGL2-3'UTR luciferase reporter vector and control vector were constructed and inoculated into MCF-7 cells in 84-well culture plate. When the cells grew to $80 \% \sim 90 \%$ fusion degree, miRNA was co-transfected to construct each vector and $0.5 \mu \mathrm{g}$ $\beta$-galactosidase expression plasmid was used as positive control.

After 48 hours of transfection, the cells were collected and analysed for luciferase activity with luciferase activity kit. The cells were placed in thermo for determination. The $\beta$-galactosidase activity in each well was detected by $\beta$-galactosidase activity detection kit. Luciferase activity, divided by $\beta$-galactosidase activity, was the relative luciferase activity of the pore. Finally, real-time fluorescence quantification was performed. Quantitative real time PCR (qRT-PCR) reaction system: $2 \times$ SYBR Mix $10 \mu \mathrm{L}$, Taq DNA polymerase $5 \mathrm{U} / \mu \mathrm{L}$ ) $0.2 \mu \mathrm{L}$, specific primers $(5 \mu \mathrm{mol} / \mathrm{L})$ $0.4 \mu \mathrm{L}$, reverse transcription product $2.0 \mu \mathrm{L}$, non-enzyme water $7.4 \mu \mathrm{L}$. Amplification conditions: $95.0{ }^{\circ} \mathrm{C}, 3 \mathrm{~min}$ denaturation; $95.0^{\circ} \mathrm{C} 12 \mathrm{~s} ; 62.0^{\circ} \mathrm{C} 35 \mathrm{~S}, 40$ cycles; melting curve analysis from $62.0^{\circ} \mathrm{C}$ to $95.0^{\circ} \mathrm{C} ; 2-\Delta \Delta \mathrm{CT}$ for gene or miRNA expression, $\Delta \Delta \mathrm{CT}$ $=$ (ctmirna-ctu6) cancer - (ctmirna-ctu6) adjacent to cancer. The expression of PLAGL2 tookGAPDH as internal reference.

Reaction system: $2 \times$ Sybr Mix $10 \mu \mathrm{L}$, Primer (10 $\mu \mathrm{mol} / \mathrm{L}) 0.4 \mu \mathrm{L}$, sterilised distilled water $7.2 \mu \mathrm{L}$, cDNA template $0.4 \mu \mathrm{L}$. Real-time PCR apparatus was placed at $95.0^{\circ} \mathrm{C}$ for 30 seconds; $95.0^{\circ} \mathrm{C}$ $5 \mathrm{~s}, 55.0^{\circ} \mathrm{C} 30 \mathrm{~s}, 72^{\circ} \mathrm{C} 10 \mathrm{~s}, 40$ cycles; $72^{\circ} \mathrm{C}$ for 5 minutes; melting curve analysis starts from $62.0^{\circ} \mathrm{C}$ to $95.0^{\circ} \mathrm{C}$ and stops.

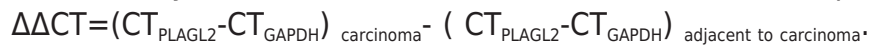

SPSS version 20.0 software was used for statistical analysis of the data. Quantitative variables tested by paired- and independent-samplest-test, $p<0.05$ as significant difference.

\section{RESULTS}

Expression of miR-22-3p in breast cancer tissues and para-cancerous tissues, detected by qRT-PCR, and the expression of miR-22-3p in breast cancer, was decreased compared with para-cancerous tissues, with statistical significance $(p<0.001$, Figure 1a).
MCF-7 cells were transfected with miR-22-3p mimics and control sequence, respectively; and cell proliferation was detected by CCK8. The results showed that 48 and 72 hours after transfection, cell proliferation rate of miR-22-3p mimics group was lower than that of control group, and the difference was statistically significant $(p=0.018$ and $p<0.001$, respectively, Figure 1b).

Table I: Primersets used for RT-PCR in this study.

\begin{tabular}{|l|l|l|}
\hline Primer set & Primers & Sequence $\left(5^{\prime}-3^{\prime}\right)$ \\
\hline \multirow{2}{*}{ GAPDH } & Forward & CATGTTCGTCATGGGGTGAACCA \\
\cline { 2 - 3 } & Reverse & AGTGATGGCATGGACTGTGGTCAT \\
\hline \multirow{2}{*}{ PLAGL2 } & Forward & GAGGCCCTCAGCTCAGTTT \\
\cline { 2 - 3 } & Reverse & CAAATGGTTCAGGCTGGTGC \\
\hline
\end{tabular}
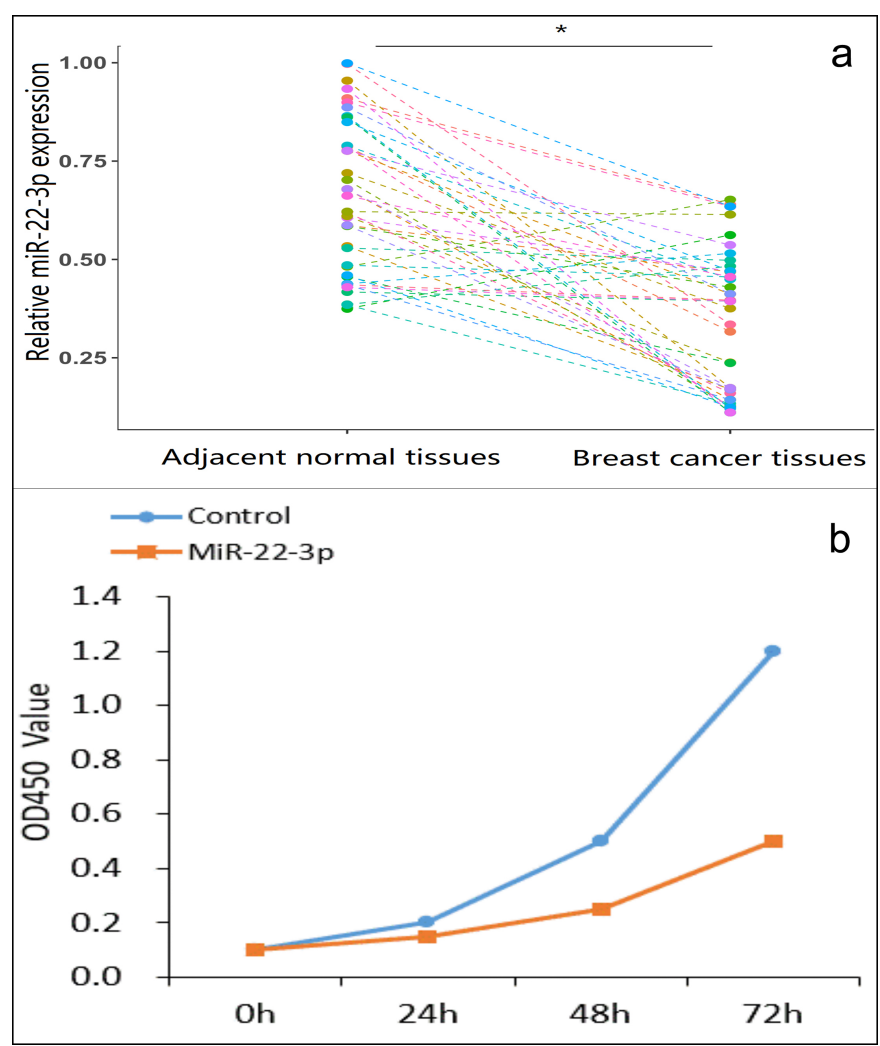

Figure 1: (a) The expression of miR-22-3p was lower in breast cancer tissues than in para-cancerous tissues. (b) The effect of miR-22-3p on the proliferation of MCF-7 cells.

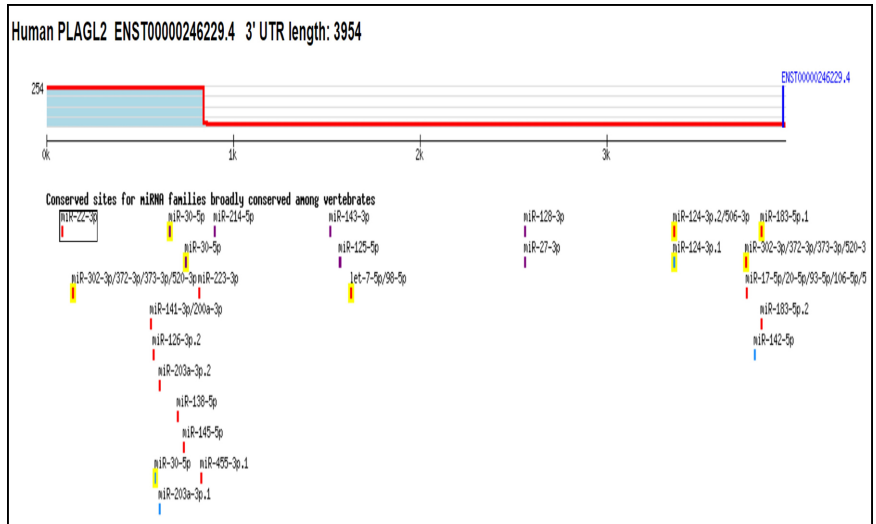

Figure 2: The prediction of Targetscan online software. 


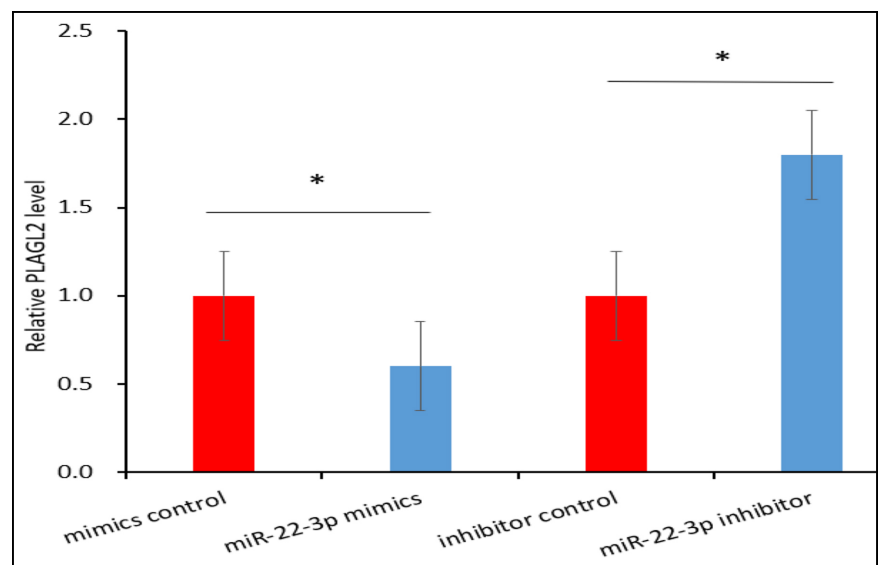

Figure 3: The effect of miR-22-3p on the expression of PLAGL2 in MCF-7 cells.

TargetScan found that miR-22-3p has one binding site with the highly expressed oncogene PLAGL2 at 3'UTR (Figure 2) in breast cancer.

QRT-PCR results showed that after transfection of miR-22-3p mimics, the expression of PLAGL2 in MCF-7 cells decreased, while after transfection of miR-22-3p inhibitor, the expression of PLAGL2 in MCF-7 cells increased and the difference was statistically significant $(p=0.001$ and $p<0.001$, Figure 3 ).

\section{DISCUSSION}

MiR-22-3p is derived from the $3^{\prime}$ end arm of miR-22 precursor, and its expression is not consistent in tumors. The expression of miR-22-3pdecreasedinlung cancer, ${ }^{5}$ cervical cancer, ${ }^{6}$ osteosarcoma, ${ }^{7}$ and hepatocellular carcinoma; ${ }^{8}$ but increased in urine of patients with bladder cancer. ${ }^{9}$ In this study, expression of miR-22-3p was detected in breast cancer tissues and adjacent tissues. The results showed that the expression of miR-22-3p in breast cancer tissues was lower than that in adjacent tissues. This is consistent with previous literature reports. ${ }^{10}$ However, the mechanism of miR-22-3p targeting regulation of breast cancer cells is not fully understood. In this study, the growth curve experiment showed that increasing the expression of miR-22-3p in breast cancer cells MCF-7 inhibited the growth of MCF- 7 cells. This study confirmed that miR-22-3p can inhibit the proliferation of breast cancer cells and play an anti-tumor role in breastcancer.

Subsequently, it was predicted that the target gene of miR-22-3p using the online software TargetScan and found that pleomorphic adenoma gene-like protein 2 (PLAGL2) might be the target gene of miR-22-3p. PLAGL2 is a class of Zinc finger proteins derived from the pleomorphic adenoma gene (PLAG) family which composed of three members (PLAG1, PLAGL1, and PLAGL2) with highly conserved structure and function exhibiting antiproliferative effects on tumor cells. ${ }^{11}$ More and more evidence has shown that PLAGL2 is involved in the progression of a variety of cancers, including liver cancer, stomach cancer, colorectal cancer, lung adenocarcinoma, neuroblastoma and bladder urothelial carcinoma malignant glioma, and plays a central role in tumorigenesis. ${ }^{11-20}$ In addi- tion, the authors used the online software TargetScan for predictive analysis and found that miR-22-3p could bind to PLAGL2 gene 3'UTR. Importantly, the overexpression of $P L A G L 2$ in breast cancer may be related to the low expression of miR-22-3p. It was proposed a new modulator mechanism that miR-22-3p suppresses proliferation, migration and invasion of breast cancer cells by regulating PLAGL2, which may provide an effective strategy for breast cancer treatment.

The qRT-PCR results showed that the expression levels of PLAGL2 was dramatically downregulated in overexpression of miR-22-3p in human breast cancer cells (MCF-7). Furthermore, overexpression of PLAGL2 could significantly reduce the number of miR-22-3p in human breast cancer cells (MCF-7). In other words, miR-22-3p can affect breast cancer cells migration and invasion via targeting PLAGL2. However, the results of this study need to be further confirmed in subsequentstudies.

\section{CONCLUSION}

MiR-22-3p was frequently downregulated in human breast cancer samples and cell lines. Overexpression of miR-22-3p inhibited the migration and invasion of breast cancer cell through regulation of $P L A G L 2$ expression. MiR-22-3p might be a novel target for treatment of breast cancer patients.

\section{ACKNOWLEDGEMENT:}

This project was supported by the health commission of Hubei Province scientific research project (No. WJ2019H510) and the Natural Science Foundation of Inner Mongolia Autonomous Region (No. 2015MS0877), China.

\section{ETHICAL APPROVAL:}

This study had prior formal approval of the Ethical and Research Committee of People's Hospital of China Three Gorges University.

\section{PATIENTS' CONSENT:}

Informed consents were obtained from the patients.

\section{CONFLICT OF INTEREST:}

The authors declared no conflict of interest.

\section{AUTHORS' CONTRIBUTION:}

TF, CQW: Conception, design and drafted of the work.

XTL, HY, JZ: Design and of the work, acquisition, analysis, interpretation of data.

YJS: Drafted and reviewed the paper, advices and final approval.

\section{REFERENCES}

1. Zhou W, Fong MY, Min Y, Somlo G, Liu L, Palomares MR, et al. Cancer-secreted miR-105 destroys vascular endothelial barriers to promote metastasis. Cancer cell 2014; 25(4): 501-15. doi: 10.1016/j.ccr.2014.03.007.

2. Xu B, Zhang X, Wang S, Shi B. MiR-449a suppresses cell migration and invasion by targeting PLAGL2 in breast cancer. Pathol Res Pract 2018; 214(5):790-5. doi: 10.1016/j.prp.2017.12.012. 
3. Monroig PD, Chen L, Zhang S, Calin GA. Small molecule compounds targeting miRNAs for cancer therapy. Advanced Drug Delivery Reviews 2015; 81: 104-16. doi: 10.1016/j.addr.2014.09.002.

4. Nair MG, Somashekaraiah VM, Ramamurthy V, Prabhu JS, Sridhar TS. miRNAs: Critical mediators of breast cancer metastatic programming. Exp Cell Res 2021, 401(1): 112518. doi: 10.1016/j.yexcr.2021.112518.

5. Wenlong $H$, Yeying $Z$, Shulan $X$. LncRNA NNT-AS1 promotes non-small cell lung cancer progression through regulating miR-22-3p/YAP1 axis. Thorac Cancer 2020, 11(3): 549-560. doi: 10.1111/1759-7714.13280.

6. Lv KT, Liu Z, Feng J, Zhao W, Hao T, Ding WY, et al. MiR-22-3p Regulates cell proliferation and inhibits cell apoptosis through targeting the elF4EBP3 Gene in human cervical squamous carcinoma cells. Int J Med Sci 2018; 152(2):142-52. doi: 10.7150/ijms.21645.

7. Xin M, Qiao Z, Li J, Liu J, Song S, Zhao X, et al. miR-22 inhibits tumor growth and metastasis by targeting ATP citrate lyase: evidence in osteosarcoma, prostate cancer, cervical cancer and lung cancer. Oncotarget 2016; 7(28):44252-65. doi: 10.18632/oncotarget.10020.

8. Chen J, Wu FX, Luo HL, Liu JJ, Luo T, Bai T, et al. Berberineupregulates miR-22-3p to suppress hepatocellular carcinoma cell proliferation by targeting Sp1. Am J Transl Res 2016; 8(11):4932-41.

9. Du L, Jiang $X$, Duan W, Wang R, Wang L, Zheng G, et al. Cell-free microRNA expression signatures in urine serve as novel noninvasive biomarkers for diagnosis and recurrence prediction of bladder cancer. Oncotarget 2017; $8(25)$ : 40832-42. doi: 10.18632/oncotarget.16586.

10. Damavandi Z, Torkashvand S, Vasei M, Soltani BM, Tavallaei M, Mowla SJ. Aberrant expression of breast development-related MicroRNAs, miR-22, miR-132, and miR-212, in breast tumor tissues. J Breast Cancer 2016; 19(2):148-55. doi: 10.4048/jbc.2016.19.2.148.

11. Hu W, Zheng S, Guo H, Dai B, Ni J, Shi Y, et al. PLAGL2EGFR-HIF-1/2 $\alpha$ Signaling loop promotes HCC progression and erlotinib insensitivity. Hepatology 2021; 73(2): 674-91. doi: 10.1002/hep.31293.

12. Wu L, Zhao N, Zhou Z, Chen J, Han S, Zhang X, et al.
PLAGL2 promotes the proliferation and migration of gastric cancer cells via USP37-mediated deubiquitination of Snail1. Theranostics 2021; 11(2): 700-14. doi: 10.7150/thno. 47800.

13. Liu B, Lu C, Song YX, Gao G, Sun JX, Chen XW, et al. The role of pleomorphic adenoma gene-like 2 in gastrointestinal cancer development, progression, and prognosis. Int J Clin Exp Pathol 2014; 7(6):3089-100.

14. Zhou Z, Wu L, Liu Z, Zhang X, Han S, Zhao N, et al. MicroRNA-214-3p targets the PLAGL2-MYH9 axis to suppress tumor proliferation and metastasis in human colorectal cancer. Aging (Albany NY) 2020; 12(10): 9633-57. doi: 10.18632/aging.103233.

15. Martin ES, Tonon G, Sinha R, Xiao Y, Feng B, Kimmelman $A C$, et al. Common and distinct genomic events in sporadic colorectal cancer and diverse cancer types. Cancer Res 2007; 67(22):10736-743. doi: 10.1158/0008-5472. CAN-07-2742.

16. Gao N, Ye B. Circ-SOX4 drives the tumorigenesis and development of lung adenocarcinoma via sponging miR-1270 and modulating PLAGL2 to activate WNT signaling pathway. Cancer Cell Int 2020; 20:2. doi: 10.1186/s12935-019-1065-x. eCollection 2020.

17. Yang YS, Yang MC, Weissler JC. Pleiomorphic adenoma gene-like 2 expression is associated with the development of lung adenocarcinoma and emphysema. Lung cancer 2011; 74(1):12-24. Doi: 10.1016/j.lungcan.2011.02.006.

18. Zhao Z, Shelton SD, Oviedo A, Baker AL, Bryant CP, Omidvarnia $\mathrm{S}$, et al. The PLAGL2/MYCN/miR-506-3p interplay regulates neuroblastoma cell fate and associates with neuroblastoma progression. J Exp Clin Cancer Res 2020; 39: 41.

19. Zheng $H$, Ying $H$, Wiedemeyer R, Yan H, Quayle SN, Ivanova EV, et al. PLAGL2 regulates Wnt signalling to impede differentiation in neural stem cells and gliomas. Cancer cell 2010; 17(5):497-509. doi: 10.1016/j.ccr.2010. 03.020 .

20. Genyi Q, Yong X, Wan Shaw P, Yang G. Expression of PLAGL2 in bladder urothelial carcinoma and its relationship to lymph node metastasis and survival. Sci Rep 2018; 8(1):6044. doi: 10.1038/s41598-018-24526-5. 